\title{
Application of abscisic acid (S-ABA) at different stages of ripening on color development of 'Rubi' table grape
}

\author{
Aplicação do ácido abscísico (S-ABA) durante a \\ maturação no desenvolvimento da cor da uva fina de \\ mesa 'Rubi'
}

\begin{abstract}
Luana Tainá Machado Ribeiro"; Maíra Tiaki Higuchi'; Aline Cristina de Aguiar²; Gabriel Danilo Shimizu'; Leandro Simões Azeredo Gonçalves'3; Sergio Ruffo Roberto ${ }^{3 *}$
\end{abstract}

\section{Highlights}

S-ABA was applied at different stages of ripening of 'Rubi' grape.

$S$-ABA increased total anthocyanins and improved color attributes of the grapes.

One application of S-ABA is sufficient to improve color development.

\begin{abstract}
The color of the berries is an important aspect of the quality of table grapes and crucial for marketing. The 'Rubi' table grapes grown in the subtropical climate generally lack color intensity due to the inhibition of anthocyanins by high temperatures during ripening. The exogenous application of abscisic acid (S-ABA) can be used to overcome this problem as the accumulation of anthocyanins in the berry skin is regulated by this plant growth regulator. The objective of this study was to assess the effect of the exogenous application of S-ABA at different stages of ripening on color development in 'Rubi' table grapes using the soluble solids (SS) content as a marker of ripening. The study was conducted during two seasons in commercial vineyards. The first trial was conducted in Marialva, Parana, Brazil, during the 2019 summer season crop (harvest in December). S-ABA (400 $\mathrm{mg} \mathrm{L}^{-1}$ ) was exogenously applied at different stages of ripening of 'Rubi' table grapes (determined by the SS content of the berries): control (without application); SS = 8-9 ${ }^{\circ} \mathrm{Brix}$; SS = 10-11 ${ }^{\circ} \mathrm{Brix}$; SS = 8-9 ${ }^{\circ}$ Brix (two applications; the second one applied 10 days after the first); and SS = 10-11 ${ }^{\circ}$ Brix (two applications; the second one applied 10 days after the first). The second trial was conducted in Cambira, Parana, Brazil, during the 2020 off-season crop (harvest in May). S-ABA (400 $\mathrm{mg} \mathrm{L}^{-1}$ ) was exogenously applied at different stages of ripening of 'Rubi' grapes: control (without application); SS = 6-7 ${ }^{\circ} \mathrm{Brix}$; SS = 7-8 ${ }^{\circ} \mathrm{Brix}$; SS = 9-10 ${ }^{\circ} \mathrm{Brix} ; \mathrm{SS}=6-7^{\circ} \mathrm{Brix}$ (two applications; the second one applied 14 days after the first); SS = 7-8 ${ }^{\circ} \mathrm{Brix}$ (two applications; the second one applied 14 days after the first); and SS = 9-10 ${ }^{\circ}$ Brix (two applications; the

1 PhD Students in Agronomy, Universidade Estadual de Londrina, UEL, Londrina, PR, Brazil. E-mail: luuanataina@ hotmail.com; maira.tiaki@gmail.com

2 M.e Student in Agronomy, UEL, Londrina, PR, Brazil. E-mail: aguiar.alinec@gmail.com

3 Profs. Drs., UEL, Londrina, PR, Brazil. E-mail: sroberto@uel.br; leandrosag@uel.br

* Author for correspondence
\end{abstract}

Received: May 01, 2021 - Approved: Oct. 22, 2021 
second one applied 14 days after the first). A randomized block design was used as the statistical model with four replications, and each plot consisted of one vine. The variables analyzed were total anthocyanin contents, color index (CIRG), and color attributes $\left(L^{*}, C^{*}, h^{\circ}\right.$, and $\left.\Delta E\right)$ of berry skin. The total anthocyanin accumulation and color attributes of the berries were evaluated every 10 and 7 days after the first application of S-ABA until harvest in the first and second trials, respectively, and the other variables were evaluated at harvest. In the summer-season crop, when the SS content was 8-11 ${ }^{\circ} \mathrm{Brix}$, the application of S-ABA increased the concentration of the total anthocyanins 4 times compared to that in the control, improving berry color development. Furthermore, in the off-season crop, when the SS content was 6-10 ${ }^{\circ}$ Brix, the application of S-ABA increased the concentration of total anthocyanins 2-3 times compared to that in the control, improving the color attributes of berries. In both crops, a single application of the plant growth regulator was sufficient to intensify the color of the berries.

Key words: Total anthocyanin content. Color. Plant growth regulator. Vitis vinifera L.

\section{Resumo}

A cor das bagas é um aspecto importante de qualidade e comercialização de uvas de mesa. A uva fina de mesa 'Rubi' produzida em clima subtropical geralmente apresenta deficiência de cor devido à inibição da formação de antocianinas pelas altas temperaturas durante a maturação. Um dos métodos utilizados para superar esse problema é a aplicação exógena de ácido abscísico (S-ABA), uma vez que o acúmulo de antocianinas na casca das bagas é controlado por esse regulador vegetal. O objetivo deste trabalho foi determinar o efeito da aplicação do S-ABA em diferentes fases de maturação no desenvolvimento da cor da uva fina de mesa 'Rubi', visando o incremento e uniformização da cor dos seus cachos, tendo como referência o teor de sólidos solúveis (SS) das bagas. O experimento foi avaliado em dois ensaios a campo, em pomares comerciais. O primeiro ensaio foi realizado em Marialva, Paraná, Brasil, durante a safra de verão (colheita em dezembro) de 2019. Os tratamentos foram constituídos da aplicação de S-ABA na concentração de $400 \mathrm{mg}$ $\mathrm{L}^{-1}$, em diferentes fases de maturação da uva 'Rubi', de acordo com o teor de SS das bagas, assim descritos: controle (sem aplicação); SS = 8-9 ${ }^{\circ}$ Brix; SS = 10-11 ${ }^{\circ}$ Brix; SS = 8-9 ${ }^{\circ}$ Brix em duas aplicações, sendo a segunda realizada aos 10 dias após a primeira; e SS = 10-11 Brix, em duas aplicações, sendo a segunda realizada aos 10 dias após a primeira. O segundo ensaio foi realizado em Cambira, Paraná, Brasil, durante a safra temporona ou de outono (colheita em maio) de 2020. Os tratamentos foram constituídos da aplicação

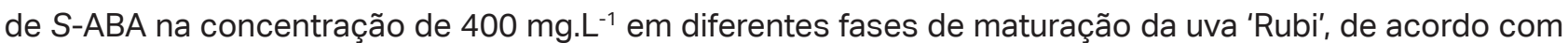
o teor de SS das bagas, assim descritos: controle (sem aplicação); SS = 6-7 ${ }^{\circ} \mathrm{Brix}$; SS = 7-8 ${ }^{\circ} \mathrm{Brix}$; SS = 9-10 'Brix; SS = 6-7 'Brix em duas aplicações, sendo a segunda realizada aos 14 dias após a primeira; SS = 7-8 'Brix em duas aplicações, sendo a segunda realizada aos 14 dias após a primeira; e SS = 9-10 Brix em duas aplicações, sendo a segunda realizada aos 14 dias após a primeira. 0 delineamento experimental de ambos experimentos foi em blocos casualizados com 4 repetições, sendo que cada parcela foi composta por uma videira. As variáveis analisadas foram antocianinas totais, índice de cor (CIRG), e atributos ( $L^{*}, C^{*}, h^{\circ}$ e $\left.\Delta E\right)$ das bagas. As avaliações quanto ao acúmulo de antocianinas totais e atributos de cor das bagas foram realizadas a cada 10 e 7 dias após a primeira aplicação do S-ABA até a colheita no primeiro e segundo experimento, respectivamente, e as demais variáveis foram avaliadas no momento da colheita. Na safra de verão, a aplicação do S-ABA quando o teor de SS era de 8-11 ${ }^{\circ}$ Brix aumentou significativamente a concentração de antocianinas totais das bagas, sendo 4 vezes maior que o controle, e também houve aumento do CIRG 
e de todos os atributos de cor. Na safra temporona, a aplicação do S-ABA também propiciou incrementos significativos sobre a concentração de antocianinas totais, sendo de 2 a 3 vezes maior que o controle, e para o CIRG e os atributos de cor também houve aumento quando o teor de SS era de 6-10 ${ }^{\circ} \mathrm{Brix}$. Nas duas safras avaliadas, uma única aplicação do regulador vegetal foi suficiente para intensificar a cor das bagas.

Palavras-chave: Antocianinas totais. Cor. Regulador vegetal. Vitis vinifera L.

\section{Introduction}

The grape industry is a very important sector in Brazil, with high impact on the generation of jobs, income, and sustainability of small agricultural farms for both fresh and processing markets, being one of the main temperate climate fruit species grown in the country (Zanus, 2015; Carvalho, Kist, \& Beling 2019). In the 2020/21 harvest, the national production was 1,416 million tons (Instituto Brasileiro de Geografia e Estatística [IBGE], 2021).

The production of grapes is high because of its consumption worldwide in the pursuit of healthy habits, as this fruit is an important source of phenolic compounds that neutralize free radicals and improve human health (Orak, 2007; Rastija, Srecnik, \& Saric, 2009; Wildman, 2016). Consumers increasingly demand optimal visual aspect of table grapes; brightly colored and uniform bunches have greater acceptance in the market. However, grapes grown in subtropical climate can be affected by high temperatures during ripening, inhibiting color development (Peppi, Fidelibus, \& Dokgozlian, 2006; Abe, Mota, Lajoto, \& Genovese, 2007).

In particular, the 'Rubi' table grape (Vitis vinifera L.) is one of the main traditional cultivars of colored table grapes grown in the country. The cultivar originated from a somatic mutation of the 'Italia' table grape found in Santa Mariana, PR, Brazil; its pink color is the only difference from the original grape. 'Rubi' is one of the most common table grapes grown in the subtropical regions such as the northern state of Parana (Nachtigal, Camargo, \& Maia, 2005; Kishino, Caramori, Roberto, \& Ricce, 2019a).

The color of the grapes is one of the main quality indicators due to the visual aspect of influencing the consumer choice and consequently the commercial value of the product. Darker and more uniform grapes are preferred compared to non-uniform grapes with lighter shades. Thus, the development of color in berries is a key feature of table grapes (Abe et al., 2007; Liang et al., 2009; Mattiuz, Miguel, Galati, \& Nachtigal, 2009; Mascarenhas, Guerra, Aquino, \& Leão, 2013; Roberto et al., 2013).

Berry color is associated with the amount and composition of anthocyanins in the skins. Anthocyanins are phenolic compounds found in vegetables and are responsible for blue, purple, and all shades of red colors in fruits, flowers, and leaves. The accumulation of these anthocyanins in berries begins at the onset of maturation (veraison), when various physiological processes occur and the berries begin to soften and change color (Ribichaud \& Noble, 1990). Abscisic acid (ABA) is known to participate in these color changes, and an increase in its levels precedes this phenological phase (Coombe \& Hale, 1973; Gambetta, Matthews, Shaghasi, Mcelrone, \& Castellarin, 2010; Koyama, Sadamatsu, \& Yamamoto, 2010; Jia et al., 2011). 
Previous studies have demonstrated that exogenous application of $A B A$ in grapes can increase the concentration of anthocyanins in the berry skin; however, the cost for synthesizing this plant regulator is high, preventing its use in viticulture. Recently, a cost-effective process for the biological production of ABA using fungi (Botrytis cinerea) was developed (Siewers, Kokkelink, Smedsgaard, \& Tudzynski, 2006; Owen et al., 2009). Subsequently, it was demonstrated that the application of the S-ABA enantiomer at veraison increased the concentration of anthocyanins in the berry skin, resulting in better uniformity and color intensity in bunches of several table grape cultivars (Peppi et al., 2006; Roberto et al., 2012, 2013; Koyama et al., 2014; Ferrara et al., 2015; Shahab et al., 2019).

However, the difficulty encountered in the application of this plant growth regulator is determining the exact time of onset of ripening for each cultivar, as the beginning of the increase in soluble solid (SS) content, color, and softening of the berries do not occur simultaneously when grapes are grown in subtropical regions (Robinson \& Davies, 2000).

The objective of this study was to determine the effect of applying S-ABA at different stages of ripening on the color development of 'Rubi' table grapes, with reference to the SS contents of the berries.

\section{Materials and Methods}

The experiment was conducted in two commercial vineyards of 'Rubi' table grape (Vitis vinifera L.) grafted on 11-year-old 'IAC766 Campinas' rootstock. The first trial was conducted at Marialva, Parana state, Brazil
(2329'52"8S, 5147'58"0W, elevation 570 m a.s.l.), during the 2019 summer harvest (July to December). The second trial was conducted at Cambira, Parana state, Brazil $\left(23^{\circ} 35^{\prime} S\right.$, $51^{\circ} 34^{\prime} \mathrm{W}$, elevation $1,017 \mathrm{~m}$ a.s.I.), during the 2020 off-season (January to June). According to Köppen's classification, the region's climate is $\mathrm{Cfa}$, subtropical with an average annual temperature of $20.7^{\circ} \mathrm{C}$ and an average annual precipitation of $1,600 \mathrm{~mm}$ (Caviglione, Kiihl, Caramori, \& Oliveira, 2000).

The vines in both vineyards were cultivated in an overhead trellis system, covered by a black plastic mesh with $18 \%$ light retention, and spaced at $3.0 \times 9.0 \mathrm{~m}$ and 2.5 $\times 3.5 \mathrm{~m}$ in Marialva and Cambira, respectively. The cane-pruning system with 7-8 buds retained per cane, followed by the application of hydrogen cyanamide at $3.0 \%$ only on the two terminal buds for uniform budburst and development. The other agricultural traits in the vineyards were the usual ones adopted in the region for table grapes (Roberto et al., 2012; Shahab et al., 2019).

The cis-abscisic acid (S-ABA) isomer was provided by Valent BioSciences ${ }^{\circledR}$ Corporation and Sumitomo Chemical (Illinois, USA), containing $100 \mathrm{~g} \mathrm{~L}^{-1}$ of the active ingredient (Protone ${ }^{\circledR}$ ). The randomized block design was used as a statistical model with four replications in Marialva and Cambira, and each plot consisted of one vine. S-ABA was applied at a concentration of $400 \mathrm{mg} \mathrm{L}^{-1}$ (Roberto et al., 2012, 2013).

In Marialva, treatments were applied at different stages of ripening, with the SS content of the berries as follows: control (no application); SS = 8-9 ${ }^{\circ}$ Brix; SS = 10-11 ${ }^{\circ}$ Brix; SS $=8-9{ }^{\circ}$ Brix in two applications, with the second performed 10 days after the first; and 
berries SS $=10-11^{\circ}$ Brix in two applications, with the second performed 10 days after the first one. In Cambira, the following treatments were applied: control (no application); SS = 6-7 ${ }^{\circ}$ Brix; SS $=7-8{ }^{\circ}$ Brix; SS $=9-10^{\circ}$ Brix; SS $=6-7^{\circ}$ Brix in two applications, with a second performed 14 days after the first one; SS = 7-8 ${ }^{\circ}$ Brix in two applications, with a second performed 14 days after the first one; and SS = 9-10 ${ }^{\circ}$ Brix in two applications, with a second performed 14 days after the first one.

To assess the SS content of the berries, 40-50 berries were randomly collected from the vineyards before application. Once the moment of each application was determined, a back sprayer was used at a pressure of 568.93 psi (39.22 bar) with JA1 hollow jet cone nozzles, providing complete and uniform coverage. The spray volume was $800 \mathrm{~L} \mathrm{ha}^{-1}$, and the solution was applied to the bunches until run-off. The non-ionic spreader Break $\operatorname{Thru}^{\circledR}\left(0.3 \mathrm{~mL} \mathrm{~L}^{-1}\right)$ was added to the solution.

The evaluations were conducted at 10,20 , and 30 days and at $7,14,21,28,35$, 42 , and 49 days after the first application for the Marialva and Cambira trials, respectively, the last being at harvest when the SS content of the berries stabilized. For this purpose, 10 berries were collected from each plot from the previous five marked bunches, with two berries from the middle part of the bunch. The variables analyzed were total anthocyanins, color index (CIRG), residual color difference $(\Delta E)$, and color attributes of berries, such as $L^{*}$ (lightness), $C^{*}$ (chroma), and $h^{\circ}$ (hue).

For total anthocyanin content analysis, 10 berries per plot were used, whose skins were removed using a scalpel blade, taking care to remove only the skin, without pulp. The skins were washed once with water, then with distilled water, and dried with paper. Then, a 3-g skin sample was placed in a polystyrene tube with $30 \mathrm{~mL}$ of acidified methanol $(1 \% \mathrm{HCl}+99 \%$ methanol) and kept in the dark at room temperature at $22{ }^{\circ} \mathrm{C}$ for $48 \mathrm{~h}$. Subsequently, the tubes were removed from the dark and manually shaken for $5 \mathrm{~s}$. The absorbance of each sample was determined using a spectrophotometer (Genesys 10S Spectrophotometer model, UV-VIS ${ }^{\circledR}$ ) at 520 $\mathrm{nm}$, with only the solvent as "blank". The results were expressed in mg of malvidin-3-glycoside per gram of skin ( $\mathrm{mg} \mathrm{g}^{-1}$ ) (Peppi et al., 2006).

The color attributes of the berries (10 berries per plot) were evaluated using the Minolta CR-10 Plus $^{\circledR}$ colorimeter and characterized as variables of its equatorial portion: $L^{*}$ (lightness), $C^{*}$ (chroma), and $h^{\circ}$ (hue). $L^{*}$ values ranged from 0 (black) to 100 (white). $C^{*}$ indicates the purity or intensity of the color, the distance from gray (achromatic) towards a pure color and is based on the values of $a^{*}$ and $b^{*}$ from the CIELab scale system, ranging from 0 for a completely neutral color; it has no arbitrary end, but intensity increases with magnitude. Hue refers to the wheel of color and is measured in angles: green, yellow, and red, which correspond to $180^{\circ}, 90^{\circ}$, and $0^{\circ}$, respectively (Lancaster, Lister, Reay, \& Triggs, 1997; Orak, 2007). From the evaluation of the color attributes, the color index of the berries (CIRG) was calculated using the formula: CIRG $=\left(180-h^{\circ}\right) /\left(L^{*}+C^{*}\right)$ (Carreño, Martínez, Almela, \& Fernández-López, 1995).

The residual color difference $(\Delta E)$ of the berries was used to calculate the color disparity between the treatments and the control of the last sampling, using the equation (Lucas et al., 2008; R. Koyama et al., 2019):

$$
\Delta E=\sqrt{\left(\Delta h^{\circ}\right)^{2}+\left(\Delta C^{*}\right)^{2}+\left(\Delta L^{*}\right)^{2}}
$$


The data set obtained from the weekly samplings from each trial, involving treatments and days to assess the significance of the main effects, were analyzed independently using a two-way ANOVA. The assumptions of normality of errors and homogeneity of variances were evaluated using the Shapiro-Wilk and Bartlett tests, respectively $(p>0.05)$. If the results were significant for interaction or for the treatment factor, the means were compared using the Tukey's test $(p<0.05)$. When observing the interaction effect between factors, the means were adjusted using polynomial regression ( $p$ $<0.05)$. All analyses were performed using the R software (R Core Team [R], 2020).

\section{Results and Discussion}

The application of S-ABA increased the concentration of total anthocyanins in the berry skins of the 'Rubi' table grapes during the two trials, regardless of the time and number of applications. In the summer harvest season, it was found that the grapes treated with S-ABA when the SS content was 10-11 'Brix, had higher means at 10 and 20 days after application (DAA), whereas at 30 DAA, all treatments in which the grapes were treated with S-ABA were statistically superior to those in the control (Table 1). As for the off-season harvest, the mean at 42 DAA was higher than that of the control, but the difference was not statistically significant. However, at 49 DAA, all treatments that received S-ABA were similar and superior to that in the control (Table 2), and the accumulation of anthocyanins was approximately three and four times greater in treatments with S-ABA, respectively.

For the summer harvest season, the highest mean observed at 10 and 20 DAA for grapes that received S-ABA when the SS content was $10-11^{\circ} \mathrm{Brix}$, may be related to the fact that at this ripening stage, the reception or the mechanistic impact of ABA was higher (Villalobos-González, Peña-Neira, Ibáñez, \& Pastenes, 2016), because the higher content of SS in the berries may have provided a higher amount of substrate to initiate the production of secondary metabolites, such as anthocyanins, responsible for the red color of the skin (Jackson, 2008; Souza, Roberto, Koyama, \& Shahab, 2020). However, at 30 DAA, there was a similarity among the treatments, and the total anthocyanin content of 'Rubi' grapes was approximately $4.2 \mathrm{mg} \mathrm{g}^{-1}$. These results are in accordance with those obtained by Keller (2015), who reported that the onset of activation of genes involved in the synthesis of anthocyanins occurs when the SS is between 9 and $10^{\circ} \mathrm{Brix}$, an interval similar to those selected in this study. 
Table 1

Analysis of variance and comparison of means for total anthocyanin content in berries of 'Rubi' table grape bunches treated with S-ABA at different stages of ripening in relation to soluble solid (SS) content in the 2019 summer season crop

\begin{tabular}{|c|c|c|c|c|c|}
\hline Sources of variation & Df & \multicolumn{4}{|c|}{ Total anthocyanin content $\left(\mathrm{mg} \mathrm{g}^{-1}\right)$} \\
\hline Treatments $(\mathrm{T})$ & 4 & \multicolumn{4}{|c|}{$8.07^{* * z}$} \\
\hline Days (D) & 3 & \multicolumn{4}{|c|}{$47.81^{* *}$} \\
\hline$T \times D$ & 12 & \multicolumn{4}{|c|}{$1.80 * *$} \\
\hline Error A & 12 & \multicolumn{4}{|c|}{0.14} \\
\hline Error B & 45 & \multicolumn{4}{|c|}{0.09} \\
\hline Means & & \multicolumn{4}{|c|}{ Days after application } \\
\hline Treatments & & 0 & 10 & 20 & 30 \\
\hline Control & & $0.2^{\text {ns }}$ & $0.3 b$ & $1.0 \mathrm{~b}$ & $1.2 b$ \\
\hline SS 8-9 ${ }^{\circ}$ Brix & & 0.1 & $0.2 b$ & $2.2 \mathrm{~b}$ & $4.2 \mathrm{a}$ \\
\hline SS $10-11^{\circ}$ Brix & & 0.3 & $1.8 \mathrm{a}$ & $3.3 \mathrm{a}$ & $4.2 \mathrm{a}$ \\
\hline SS 8-9 ${ }^{\circ}$ Brix $2 x$ & & 0.1 & $0.3 b$ & $2.3 b$ & $4.2 \mathrm{a}$ \\
\hline SS $10-11^{\circ}$ Brix $2 x$ & & 0.3 & $1.7 \mathrm{a}$ & $3.2 \mathrm{a}$ & $4.5 \mathrm{a}$ \\
\hline
\end{tabular}

$2 x$, two applications of S-ABA; Df, degrees of freedom; ${ }^{2}$, mean squares; ns, not significant; ${ }^{* *}$, significant $(p<0.01)$. Means followed by the same letters in the columns do not differ using the Tukey's test $(p<0.05)$.

Table 2

Analysis of variance and comparison of means for total anthocyanin content of berries of 'Rubi' table grape bunches treated with S-ABA at different stages of ripening in relation to soluble solid (SS) content in the 2020 off-season crop

\begin{tabular}{|c|c|c|c|c|c|c|c|c|}
\hline Sources of variation & \multicolumn{4}{|c|}{ Df } & \multicolumn{4}{|c|}{ Total anthocyanin content ( $\left.\mathrm{mg} \mathrm{g}^{-1}\right)$} \\
\hline Treatments $(\mathrm{T})$ & \multicolumn{4}{|c|}{7} & \multicolumn{4}{|c|}{$1.62^{* * z}$} \\
\hline Days (D) & \multicolumn{4}{|c|}{7} & \multicolumn{4}{|c|}{$20.61^{* *}$} \\
\hline$T \times D$ & \multicolumn{4}{|c|}{42} & \multicolumn{4}{|c|}{$0.31^{* *}$} \\
\hline Error A & \multicolumn{4}{|c|}{18} & \multicolumn{4}{|c|}{0.54} \\
\hline Error B & \multicolumn{4}{|c|}{147} & \multicolumn{4}{|c|}{0.14} \\
\hline Means & \multicolumn{8}{|c|}{ Days after application } \\
\hline Treatments & 0 & 7 & 14 & 21 & 28 & 35 & 42 & 49 \\
\hline Control & $0.1^{\text {ns }}$ & $0.1^{\text {ns }}$ & $0.2^{\text {ns }}$ & $0.2^{\text {ns }}$ & $0.5^{\text {ns }}$ & $0.5^{\text {ns }}$ & $0.9 \mathrm{~b}$ & $0.9 \mathrm{~b}$ \\
\hline SS 6- $7^{\circ}$ Brix & 0.1 & 0.1 & 0.2 & 0.4 & 0.8 & 1.3 & $2.2 \mathrm{a}$ & $2.6 \mathrm{a}$ \\
\hline SS 7-8 ${ }^{\circ}$ Brix & 0.1 & 0.1 & 0.2 & 0.4 & 0.7 & 1.4 & $1.6 \mathrm{ab}$ & $2.6 \mathrm{a}$ \\
\hline SS 9-10 ${ }^{\circ}$ Brix & 0.1 & 0.1 & 0.2 & 0.4 & 0.6 & 1.0 & $1.7 \mathrm{ab}$ & $2.5 \mathrm{a}$ \\
\hline SS $6-7^{\circ}$ Brix $2 x$ & 0.1 & 0.1 & 0.2 & 0.4 & 1.0 & 1.1 & $1.9 a$ & $3.0 \mathrm{a}$ \\
\hline SS 7-8 ${ }^{\circ}$ Brix $2 x$ & 0.1 & 0.1 & 0.1 & 0.2 & 0.7 & 0.7 & $1.8 \mathrm{ab}$ & $3.0 \mathrm{a}$ \\
\hline SS 9-10 ${ }^{\circ}$ Brix $2 x$ & 0.1 & 0.1 & 0.1 & 0.3 & 0.9 & 0.8 & $1.8 \mathrm{ab}$ & $2.5 \mathrm{a}$ \\
\hline
\end{tabular}

$2 x$, two applications of S-ABA; Df, degrees of freedom; $z$, mean squares; ns, not significant; **, significant $(p<0.01)$. Means followed by the same letters in the columns do not differ using the Tukey's test $(p<0.05)$. 
By contrast, at 42 DAA, the highest means were observed for bunches that received S-ABA when the SS content was 6-7 ${ }^{\circ} B$ rix in the off-season, which can be explained by the fact that at this stage of ripening, the berries in this treatment group had a longer period of anthocyanin accumulation than in those in which the application was performed later (Giribaldi, Hartung, \& Schubert, 2010). The increase in the concentration of anthocyanins may or may not coincide with the peak accumulation of their SS and AT contents, depending on the season and the weather conditions (Ribéreau-Gayón, Glories, Maujean, \& Dubourdieu, 2006). This fact explains the difference in the beginning of the total anthocyanin concentration between the two seasons. Similar results were found by Villalobos-González et al. (2016) in Carménère grapes; even after 40 DAA, the accumulation of anthocyanins remained high in the berries treated with S-ABA.

It is essential for the winegrowers to know the ideal period to apply ABA (Giribaldi et al., 2010). Based on the results obtained in our trials, the exogenous application of S-ABA can be considered essential for the development of anthocyanin accumulation in the 'Rubi' table grape, which lacks optimal color development when grown in tropical and subtropical regions because of climatic conditions (Francis, 2000; Mattiuz et al., 2009). In addition, it is possible to conduct an application from the moment when the SS content of the berries is around $6{ }^{\circ}$ Brix and up to $11^{\circ} \mathrm{Brix}$; that is, S-ABA can be applied over a long period. Consequently, a long timeframe optimizes the use of labor, because depending on the size of the area to be applied, more time is required for the entire area to be treated.
However, it is known that an ideal stage for the application of S-ABA may vary according to the cultivar and the growing region, as some cultivars respond well to a single application, whereas others may require multiple applications; in addition, the anthocyanin concentration is influenced by climatic conditions (Yamamoto et al., 2015). Among the various environmental factors are temperature, solar radiation, and an interaction between both (Tarara, Lee, Spayd, \& Scagel, 2008). According to Ryu et al. (2020), temperatures above $30^{\circ} \mathrm{C}$, constant or even intermittent, inhibit the accumulation of anthocyanins in the berry skins, and a thermal amplitude of less than $10{ }^{\circ} \mathrm{C}$ in the postsoftening phase can impair the uniformity and color of 'Rubi' bunches (Kishino, Marur, \& Roberto, 2019b). In both harvest seasons, it was observed that one application of S-ABA was sufficient to increase the accumulation of anthocyanins; however, it is important to emphasize that the climatic conditions during the experiment were favorable, and on most days the thermal amplitude was $10^{\circ} \mathrm{C}$.

Regarding the development of anthocyanin content in the 2019 summer crop season, it was found that there was a progressive linear growth for all treatments (Figure 1). However, it was observed that bunches that received the application of S-ABA had higher rates over time $(0.1297$ to $0.1436 \mathrm{mg} \mathrm{g}^{-1}$ of total anthocyanins per day) when compared to those in the control (0.0378 $\mathrm{mg} \mathrm{g}^{-1}$ of total anthocyanins per day); the development of anthocyanins in the berry skin was faster for treatments with S-ABA. During the 2020 off-season harvest (Figure 2) and the summer harvest season, the quadratic adjustment explained the behavior of the anthocyanin content over time. All 
those receiving the application of S-ABA had higher accumulation of anthocyanins than that in the control, although, up to 35 DAA, this accumulation was similar. However, at $42 \mathrm{DAA}$, those that received S-ABA had higher rates, differing from the control, which continued with low accumulation $\left(0.1226 \mathrm{mg} \mathrm{g}^{-1}\right.$ of anthocyanins per day).

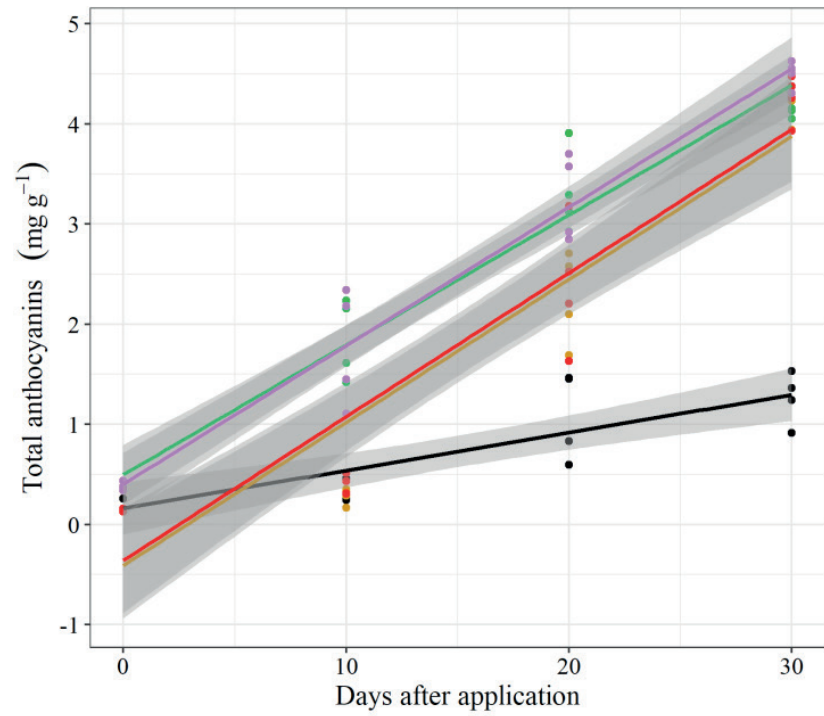

Control $\mathrm{y}=0.1613+0.0378 \mathrm{x} \quad R^{2}=0.88$

SS $8-9{ }^{\circ}$ Brix $\mathrm{y}=-0.4106+0.1429 \mathrm{x} \quad R^{2}=0.91$

SS $10-11^{\circ}$ Brix y $=0.4968+0.1297 \mathrm{x} \quad R^{2}=0.98$

SS 8-9 ${ }^{\circ}$ Brix $2 \times \mathrm{y}=-0.3599+0.1436 \mathrm{x} \quad R^{2}=0.92$

SS $10-11^{\circ}$ Brix $2 \times \mathrm{y}=0.4017+0.1384 \mathrm{x} \quad R^{2}=0.99$

Figure 1. Development of the total anthocyanin concentration in 'Rubi' table grape bunches treated with S-ABA at different stages of ripening in relation to the soluble solid (SS) content in the 2019 summer season crop. 2x, two applications of S-ABA.

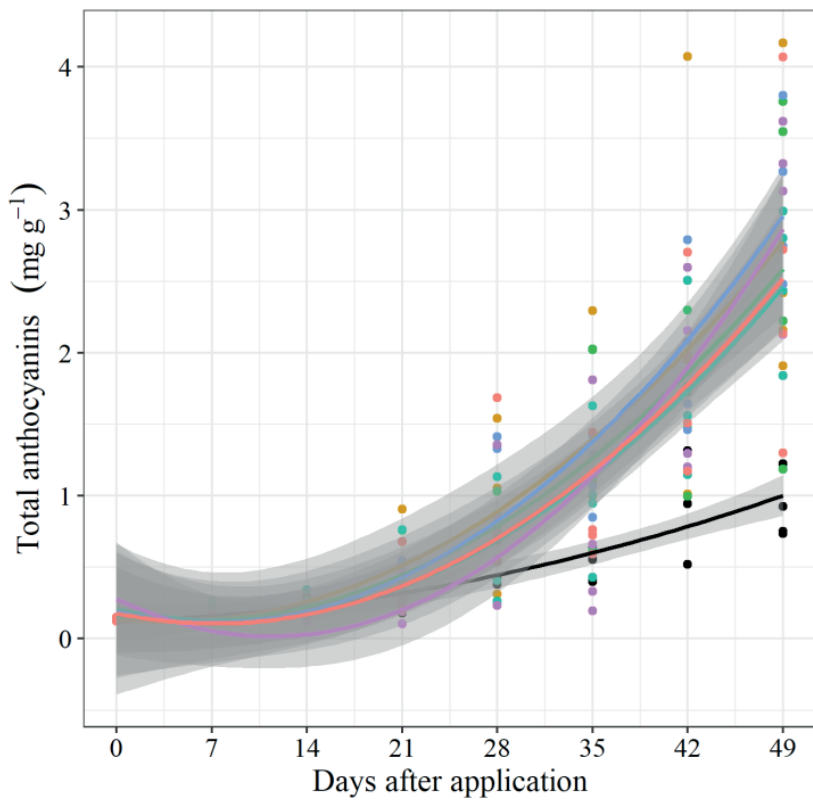

Control $\mathrm{y}=0.1226+0.003 \mathrm{x}+3 \mathrm{e}-04 \mathrm{x}^{2} \quad R^{2}=0.92$

SS 6-7 ${ }^{\circ}$ Brix $\mathrm{y}=0.1356-0.0091 \mathrm{x}+0.0013 \mathrm{x}^{2} \quad R^{2}=0.99$

SS 7-8 Brix y $=0.1622-0.0136 \mathrm{x}+0.0013 \mathrm{x}^{2} \quad R^{2}=0.98$

SS 9-10 Brix $\mathrm{y}=0.2111-0.0215 \mathrm{x}+0.0014 \mathrm{x}^{2} \quad R^{2}=0.99$

SS 6-7 ${ }^{\circ}$ Brix $2 \times \mathrm{y}=0.1912-0.0224 \mathrm{x}+0.0016 \mathrm{x}^{2} \quad R^{2}=0.98$

SS $7-8^{\circ}$ Brix $2 \times \mathrm{y}=0.2794-0.046 \mathrm{x}+0.002 \mathrm{x}^{2} \quad R^{2}=0.96$

SS 9- $10^{\circ}$ Brix $2 \times \mathrm{y}=0.1775-0.0198 \mathrm{x}+0.0014 \mathrm{x}^{2} \quad R^{2}=0.97$

Figure 2. Development of total anthocyanins in 'Rubi' table grape bunches treated with S-ABA at different stages of ripening in relation to the soluble solid (SS) content in the 2020 off-season crop. $2 x$, two applications of S-ABA. 
In both crop seasons at harvest time, $S-A B A$ treatments did not differ from each other (the confidence intervals overlapped), except for the control. This increased accumulation of total anthocyanins observed in S-ABA-treated groups can be explained by the fact that this plant regulator is a signaling agent that triggers fruit ripening and stimulates the expression of UFGT, thus regulating anthocyanin biosynthesis (Yang \& Feng, 2015).

Regarding the berry color index (CIRG), the highestmeanswere observed in the S-ABAtreated grapes, regardless of the season and number of applications. In the summer season, as observed for total anthocyanin concentration, the grapes treated with S-ABA when the SS content was $10-11^{\circ}$ Brix resulted in the highest mean values at 10 and 20 DAA (Table 3). For the off-season crop, differences among treatments were observed from 28 DAA, and the bunches treated when the SS content was 9-10 ${ }^{\circ}$ Brix in two applications had the highest mean, differing from that in the control. At 35 DAA, treatments applied when the SS content was 6-7 ${ }^{\circ}$ Brix and 7-8 ${ }^{\circ} \mathrm{Brix}$ (in one application) and 9-10 ${ }^{\circ} \mathrm{Brix}$ (in one or two applications) had better results (Table 4). However, at harvest in both seasons, the S-ABA treatments were similar, but superior to those in the control.

\section{Table 3}

Analysis of variance and comparison of means for color index (CIRG) of 'Rubi' table grape berries treated with S-ABA at different stages of ripening in relation to soluble solid content (SS) in the 2019 summer season crop

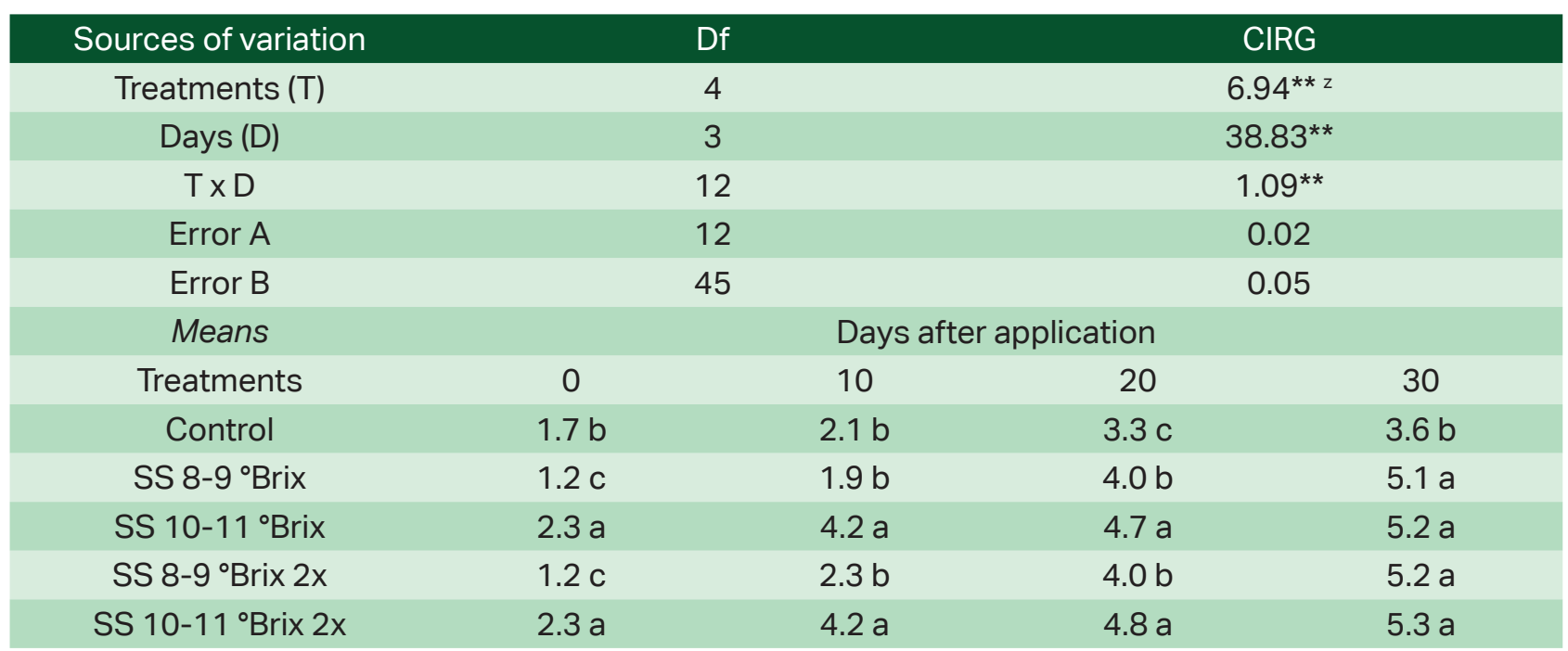

$2 x$, two applications of S-ABA; Df, degrees of freedom; $z$, mean squares; ns, not significant; **, significant ( $p<0.01)$. Means followed by the same letters in the columns do not differ using the Tukey's test $(p<0.05)$. 
Table 4

Analysis of variance and comparison of means for color index (CIRG) of 'Rubi' table grape berries treated with S-ABA at different stages of ripening in relation to soluble solid content (SS) in the 2020 off-season crop

\begin{tabular}{|c|c|c|c|c|c|c|c|c|}
\hline Sources of variation & \multicolumn{4}{|c|}{ Df } & \multicolumn{4}{|c|}{ Total anthocyanin content $\left(\mathrm{mg} \mathrm{g}^{-1}\right)$} \\
\hline Treatments $(\mathrm{T})$ & \multicolumn{4}{|c|}{7} & \multicolumn{4}{|c|}{$3.65^{* * z}$} \\
\hline Days (D) & \multicolumn{4}{|c|}{7} & \multicolumn{4}{|c|}{$38.24^{* *}$} \\
\hline$T \times D$ & \multicolumn{4}{|c|}{42} & \multicolumn{4}{|c|}{$0.62^{* *}$} \\
\hline Error A & \multicolumn{4}{|c|}{18} & \multicolumn{4}{|c|}{0.63} \\
\hline Error B & \multicolumn{3}{|c|}{147} & & \multicolumn{4}{|c|}{0.15} \\
\hline Means & \multicolumn{8}{|c|}{ Days after application } \\
\hline Treatments & 0 & 7 & 14 & 21 & 28 & 35 & 42 & 49 \\
\hline Control & $1.2^{\text {ns }}$ & $1.2^{\mathrm{ns}}$ & $1.5^{\mathrm{ns}}$ & $1.6^{\text {ns }}$ & $1.7 \mathrm{~b}$ & $1.7 \mathrm{~b}$ & $1.9 b$ & $2.3 b$ \\
\hline SS $6-7^{\circ}$ Brix & 1.2 & 1.2 & 1.6 & 2.1 & $2.5 a b$ & $3.4 \mathrm{a}$ & $3.9 \mathrm{a}$ & $4.4 \mathrm{a}$ \\
\hline SS $7-8^{\circ}$ Brix & 1.2 & 1.2 & 1.5 & 2.3 & $2.6 a b$ & $3.0 \mathrm{a}$ & $4.2 \mathrm{a}$ & $4.4 \mathrm{a}$ \\
\hline SS $9-10^{\circ}$ Brix & 1.2 & 1.2 & 1.7 & 2.1 & $2.5 a b$ & $3.2 \mathrm{a}$ & $4.1 \mathrm{a}$ & $4.5 \mathrm{a}$ \\
\hline SS $6-7^{\circ}$ Brix $2 x$ & 1.2 & 1.2 & 1.5 & 2.2 & $2.6 a b$ & $2.7 \mathrm{ab}$ & $4.5 \mathrm{a}$ & $4.7 \mathrm{a}$ \\
\hline SS 7-8 ${ }^{\circ}$ Brix $2 x$ & 1.2 & 1.2 & 1.6 & 2.1 & $2.5 a b$ & $2.7 \mathrm{ab}$ & $4.3 \mathrm{a}$ & $4.6 \mathrm{a}$ \\
\hline SS 9-10 ${ }^{\circ}$ Brix $2 x$ & 1.2 & 1.2 & 1.3 & 1.9 & $2.8 \mathrm{a}$ & $2.7 \mathrm{a}$ & $4.1 \mathrm{a}$ & $4.6 \mathrm{a}$ \\
\hline
\end{tabular}

$2 x$, two applications of S-ABA; Df, degrees of freedom; ${ }^{z}$, mean squares; ns, not significant; $* *$, significant $(p<0.01)$. Means followed by the same letters in the columns do not differ using the Tukey's test $(p<0.05)$.

According to the CIRG classification proposed by Carreño et al. (1996), the control berries were pink in color, whereas the berries treated with S-ABA, with one or two applications, were dark red in color. This difference demonstrates the effectiveness of S-ABA treatments in intensifying grape color. As one of the main factors of choice for consumers is the color of the grapes, darker and uniform color of the berries adds commercial value and may increase the grower's profit (Abe et al., 2007; Liang et al., 2009; Mattiuz et al., 2009). Yamamoto et al. (2015), Tecchio et al. (2017), and Shahab et al. (2019) have also found that treatment with S-ABA resulted in higher CIRG values for the 'Isabel', 'Niagara Rosada', and 'Benitaka' table grapes, respectively.
As previously observed for total anthocyanins, the simple linear adjustment explained the behavior of the CIRG development over time in both crop seasons. In the summer season, the S-ABA treatment groups had higher rates of CIRG per day, from 0.092 to 0.1401 , than those of the control (0.0683 of CIRG per day; Figure 3). In the off-season crop, the S-ABA treatments also had higher rates of CIRG per day, from 0.0724 to 0.0773 , than those of the control (0.0207 CIRG per day; Figure 4); therefore, in both seasons, the development of CIRG in berries was faster when S-ABA was applied. At harvest time for both seasons, at 30 DAA and 49 DAA, respectively, there were differences among S-ABA treatments, provided that the confidence intervals overlapped, except when compared to the control. 


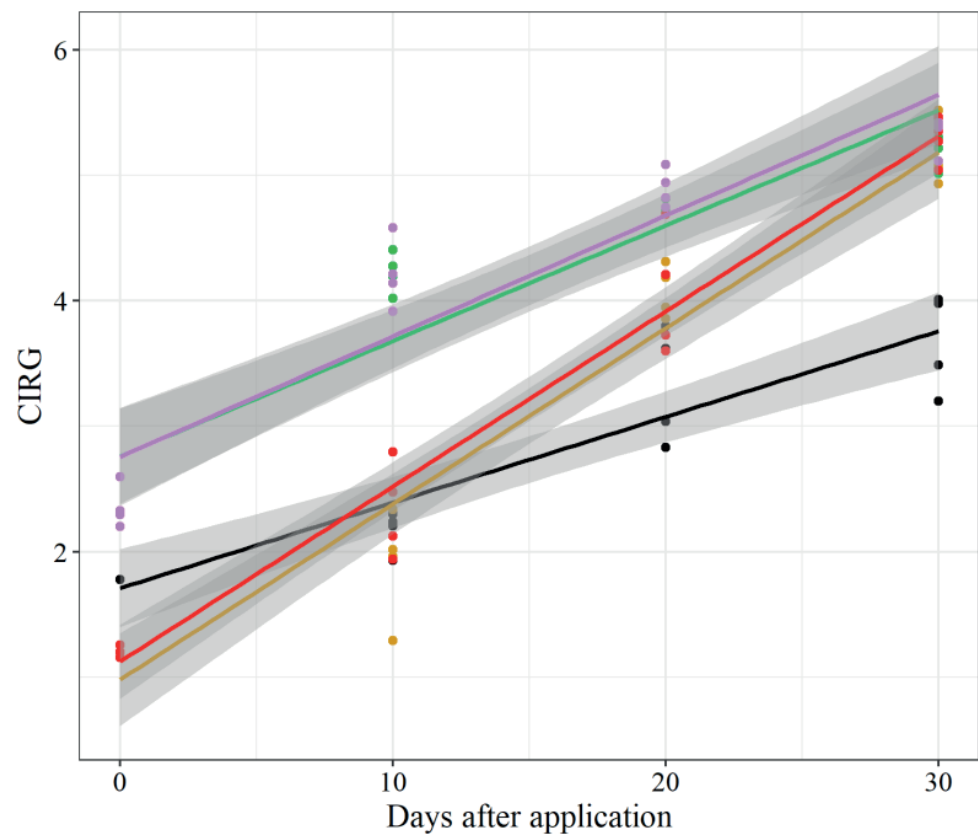

Control $\mathrm{y}=1.7095+0.0683 \mathrm{x} \quad R^{2}=0.94$ SS 8-9 ${ }^{\circ}$ Brix $\mathrm{y}=0.9797+0.1401 \mathrm{x} \quad R^{2}=0.96$ SS $10-11^{\circ}$ Brix $\mathrm{y}=2.7608+0.092 \mathrm{x} \quad R^{2}=0.88$ SS 8-9 ${ }^{\circ}$ Brix $2 \times \mathrm{y}=1.1236+0.1396 \mathrm{x} \quad R^{2}=0.99$ SS $10-11^{\circ}$ Brix $2 \times y=2.756+0.0962 x \quad R^{2}=0.89$

Figure 3. Development of the color index (CIRG) in 'Rubi' table grape berries treated with S-ABA at different stages of ripening in relation to the soluble solid (SS) content in the 2019 summer season crop. 2x, two applications of S-ABA.

Regarding the $L^{*}$ attribute for both seasons at harvest (Tables 5 and 6), the lowest means were found for the S-ABA treatment groups, regardless of the SS content and the number of applications. This finding demonstrates the effect of the plant regulator to improve the color of the berries, as the lower the $L^{*}$ value, the darker the berry skin tends to be (Roberto et al., 2012; Domingues et al., 2017; Tecchio et al., 2017). Similar observations were reported by Peppi et al. (2007, 2008); and Koyama et al. (2014) for 'Red Globe', 'Crimson Seedless' and, 'Isabel' table grapes, respectively. 


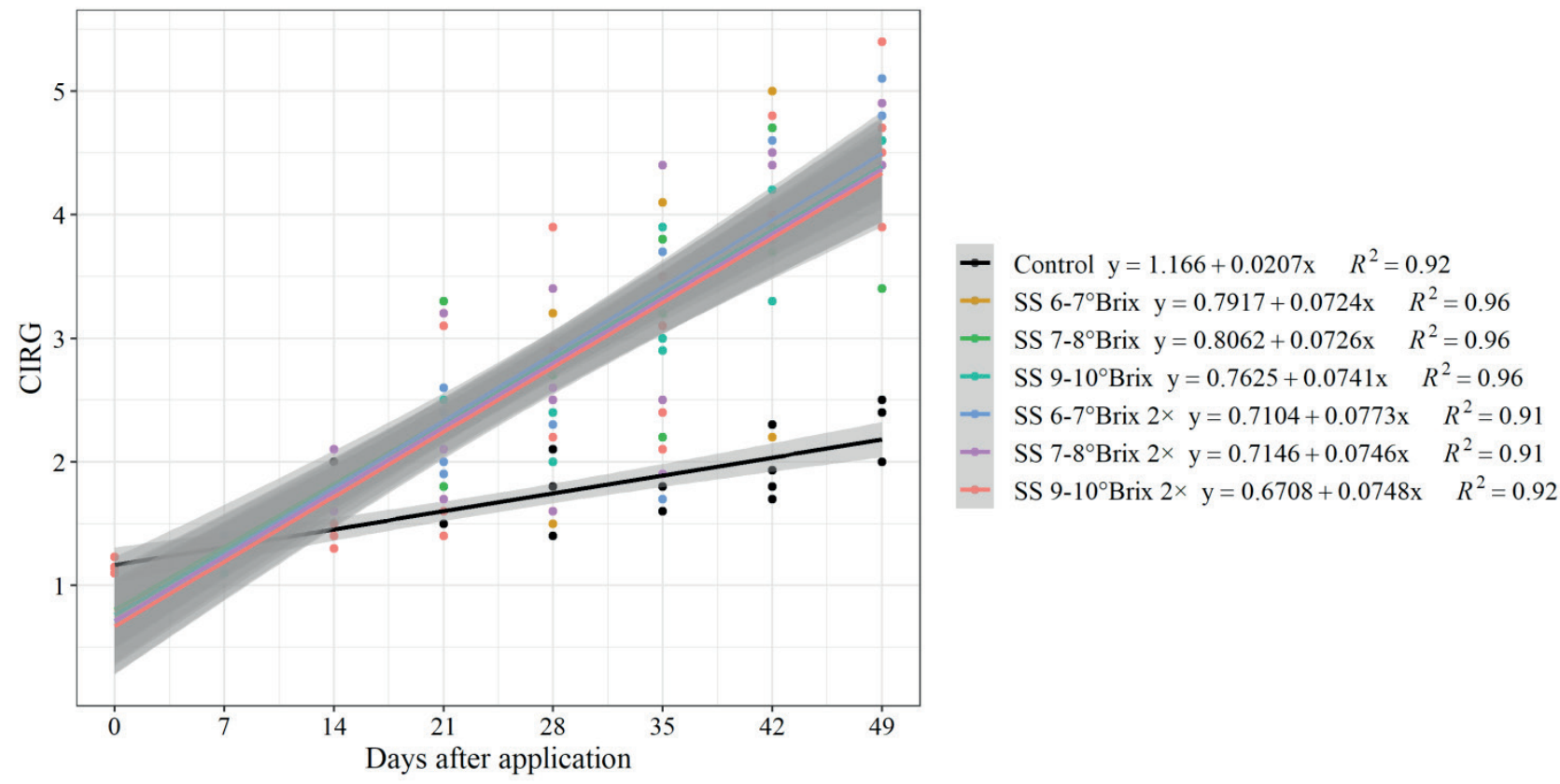

Figure 4. Development of the color index (CIRG) in 'Rubi' table grape berries treated with S-ABA at different stages of ripening in relation to the soluble solid content (SS) in the 2020 off season crop. $2 x$, two applications of S-ABA.

\section{Table 5}

$L^{*}$ (lightness), $C^{*}$ (chroma), $h^{\circ}$ (hue), and residual color difference $(\Delta E)$ of the berries of 'Rubi' table grape bunches treated with S-ABA at different stages of ripening in relation to the soluble solid (SS) content in the 2019 summer season crop

\begin{tabular}{|c|c|c|c|c|}
\hline Treatments & $L^{*}$ & $C^{*}$ & $h^{\circ}$ & $\Delta E$ \\
\hline Control & $31.8 \mathrm{a}$ & $8.1 \mathrm{a}$ & $36.9 a$ & - \\
\hline SS 8- $9^{\circ}$ Brix & $25.9 b$ & $6.7 \mathrm{~b}$ & $13.2 b$ & $24.5^{\mathrm{ns}}$ \\
\hline SS $10-11^{\circ}$ Brix & $25.7 b$ & $6.8 a b$ & $9.9 \mathrm{~b}$ & 27.7 \\
\hline SS 8-9 ${ }^{\circ}$ Brix $2 x$ & $25.3 b$ & $6.4 \mathrm{~b}$ & $13.7 b$ & 24.1 \\
\hline SS $10-11^{\circ}$ Brix $2 x$ & $25.3 b$ & $6.7 \mathrm{~b}$ & $10.3 \mathrm{~b}$ & 29.6 \\
\hline $\mathrm{F}$ & 24.1 & 4.8 & 20.9 & 4.3 \\
\hline CV (\%) & 4.2 & 8.8 & 29.5 & 9.4 \\
\hline
\end{tabular}

$2 x$, two applications of S-ABA; ns, not significant $(p<0.05)$; CV, coefficient of variation. Means followed by the same letters in the columns do not differ using the Tukey's test $(p<0.05)$. 
Table 6

$L^{*}$ (lightness), $C^{*}$ (chroma), $h^{\circ}$ (hue), and residual color difference $(\Delta E)$ of the berries of 'Rubi' table grape bunches treated with S-ABA at different stages of ripening in relation to the soluble solid (SS) content in the 2020 off-season crop

\begin{tabular}{|c|c|c|c|c|}
\hline Treatments & $L^{*}$ & $C^{*}$ & $\boldsymbol{h}^{\circ}$ & $\Delta E$ \\
\hline Control & $35.3 \mathrm{a}$ & $8.5 \mathrm{~ns}$ & $81.0 \mathrm{a}$ & - \\
\hline SS $6-7^{\circ}$ Brix & $27.7 \mathrm{~b}$ & 7.5 & $25.3 b$ & $56.2^{\text {ns }}$ \\
\hline SS $7-8^{\circ}$ Brix & $27.9 b$ & 7.2 & $28.2 \mathrm{~b}$ & 53.3 \\
\hline SS 9-10 ${ }^{\circ}$ Brix & $27.7 b$ & 7.3 & $22.5 \mathrm{~b}$ & 58.9 \\
\hline SS $6-7^{\circ}$ Brix $2 x$ & $26.8 b$ & 7.6 & $16.8 \mathrm{~b}$ & 64.7 \\
\hline SS $7-8^{\circ}$ Brix $2 x$ & $27.0 \mathrm{~b}$ & 7.9 & $18.7 \mathrm{~b}$ & 62.8 \\
\hline SS 9-10 ${ }^{\circ}$ Brix $2 x$ & $26.5 b$ & 7.7 & $20.2 b$ & 61.4 \\
\hline $\mathrm{F}$ & 15.9 & 2.1 & 18.9 & 0.6 \\
\hline CV (\%) & 5.4 & 7.8 & 34.2 & 17.3 \\
\hline
\end{tabular}

$2 x$, two applications of S-ABA; ns, not significant ( $p<0.05)$; $C V$, coefficient of variation. Means followed by the same letters in the columns do not differ using the Tukey's test $(p<0.05)$.

Regarding $C^{*}$, which defines the color saturation of the fruit surface, it was observed in the summer season that all S-ABA treatments had lower means when compared with those for the control, except for the treatment applied when the SS content of the berries was 10-11 ${ }^{\circ}$ Brix (Table 5). Moreover, 'Flame Seedless', 'Crimson Seedless' and 'Isabel' table grapes had lower means of $C^{*}$ due to the application of S-ABA (Peppi, et al., 2006, 2008; Koyama et al., 2014). However, in the off-season crop, there were no differences among the treatments (Table 6). These results are similar to those observed by Roberto et al. (2012) for 'Benitaka' grape and by Tecchio et al. (2017) for 'Niagara Rosada' grape, in which there were no differences among treatments in terms of $C^{*}$. According to Piva, Lopez and Morgan (2006) and Cantín, Fidelibus and Crisosto (2007), the lower chromatic values of the bunches treated with S-ABA represented diminished color saturation (graying) when $C^{*}$ approaches zero; however, these values do not affect the market price of the grapes (Olivares et al., 2017).

Regarding the hue $\left(h^{\circ}\right)$ of the berries, the lowest means were observed in the treatments in which S-ABA was applied, differing from the control, but without differences among them in both harvest seasons (Tables 5 and 6). Thus, the application of the plant regulator stimulates the development of the red color of berries, provided that the lower the $h^{\circ}$, the more reddish the berry color (Lima, Melo, \& Guerra, 2007; Olivares et al., 2017; Machado, Monteiro, \& Tiecher, 2019). Similar observations were reported by Olivares et al. (2017) and Shahab et al. (2019) in 'Crimson Seedless' and 'Benitaka' table grapes, respectively, in which the $h^{\circ}$ decreased during the berry development after S-ABA application. For the residual color difference $(\Delta E)$ in both harvest seasons, there was no statistical difference among S-ABA treatments, and the closer the $\triangle E$ approached zero, the more identical they were as colored surfaces (Lucas et al., 2008; 
Koyama et al., 2019). There was no difference among treatments in terms of SS content in the last evaluation (at harvest time).

To summarize, the exogenous application of S-ABA in 'Rubi' table grapes in the 2019 summer season and in the 2020 offseason, when the SS content was between 6 and $11{ }^{\circ}$ Brix, improved the concentration of anthocyanins and their color attributes. The improvement was similar between one and two applications of the plant growth regulator Applying S-ABA over a prolonged period would optimize the use of labor and machinery and is a promising approach for producing colored table grapes cultivated in the subtropical region, as grapes with better uniformity and intensity of berries obtain better prices in the market and are well accepted by consumers (Mattiuz et al., 2009; Leão, Lima, Costa, \& Trindade, 2015; Souza et al., 2020).

\section{Conclusion}

In the 2019 summer season and in the early 2020 off-season, the exogenous application of S-ABA in bunches of 'Rubi' grapes, when the SS content was 6-11 ${ }^{\circ}$ Brix, increased the concentration of total anthocyanins and improved the color development in the berries, and a single application of this plant regulator was enough to intensify the color of the berries.

\section{References}

Abe, L. T., Mota, R. V., Lajolo, F. M., \& Genovese, M. I. (2007). Compostos fenólicos e capacidade antioxidante de uvas Vitis labrusca e Vitis vinifera L. Revista Ciência e Tecnologia de Alimentos,
27(2), 394-400. doi: 10.1590/S0101-20 612007000200032

Cantín, C. M., Fidelibus, M. W., \& Crisosto, C. H. (2007). Application of abscisic acid (ABA) at véraison advanced red color develop kment and maintained postharvest quality of 'Crimson Seedless' grapes. Revista Postharvest Biology and Technology, 46(3), 237-241. doi: 10.1016/j. postharvbio.2007.05.017

Carreño, J., Martínez, A., Almela, L., \& Fernández-López, J. A. (1995). Proposal of an index for the objective evaluation of the color of red table grapes. Revista Food Research International, 28(4), 373-377. doi: 10.1016/0963-9969(95)00008-A

Carreño, J., Martínez, A., Almela, L., \&FernándezLópez, J. A. (1996). Measuring the color of table grapes. Revista Color Research \& Application, 21(1), 50-54. doi: 10.1002/ (SICI)1520-6378(199602)21:1<50::AIDCOL5>3.0.CO;2-4

Carvalho, C., Kist, B. B., \& Beling, R. R. (2019). Anuário brasileiro de horti \& fruti. Santa Cruz do Sul: Gazeta.

Caviglione, J. H., Kiihl, L. R. B., Caramori, P. H., \& Oliveira, D. (2000). Cartas climáticas do Paraná. Londrina: IAPAR.

Coombe, B. G., \& Hale, C. R. (1973). The hormone content of ripening grape berries and the effects of growth substances treatments. Plant Physiology, 51(4), 629-634. doi: 10. 1104/pp.51.4.629

Domingues, F. J., Neto, Pimentel, A. Jr., Borges, C. V., Cunha, S. R., Callili, D., Lima, G. P. P.,... Tecchio, M. T. (2017). The exogenous application of abscisic acid induce accumulation of anthocyanins and phenolic compounds of the 'Rubi'Grape. American Journal of Plant Sciences, 8(10), 2422-2432. doi: 10.4236/ ajps.2017.810164 
Ferrara, G., Mazzeo, A., Matarrese, A. M. S., Pacucci, C., Punzi, R., Faccia, M.,... Gambacorta, G. (2015). Application of abscisic acid (S-ABA) and sucrose to improve color, anthocyanin content and antioxidant activity of cv. Crimson Seedless grape berries. Australian Journal of Grape and Wine Research, 21(1), 18-29. doi: 10.1111/ajgw.12112

Francis, F. J. (2000). Anthocyanins and betalains: compositions and applications. Cereal Foods World, 45(5), 208-213.

Gambetta, G. A., Matthews, M. A., Shaghasi, T. H., Mcelrone, A. J., \& Castellarin, S. D. (2010). Sugar and abscisic acid signaling orthologs are activated at the onset of ripening in grape. Planta, 232(1), 219-234. doi: 10.1007/s00425-010-1165-2

Giribaldi, M., Hartung, W., \& Schubert, A. (2010). The effects of abscisic acid on grape berry ripening are affected by the timing of treatment. Journal International des Sciences de la Vigne et du Vin, 44(Special Issue), 9-15.

Instituto Brasileiro de Geografia e Estatística (2021). Tabela 1618: área plantada, área colhida e produção, por ano da safra e produto das lavouras. Rio de Janeiro: IBGE. Recuperado de https://sidra.ibge. gov.br/tabela/1618

Jackson, R. S. (2008). Wine science: principles and applications (3nd ed.). Amsterdam: Elsevier.

Jia, H. F., Chai, Y. M., Li, C. L., Lu, D., Luo, J. J., \& Qin, L. (2011). Abscisic acid plays an important role in the regulation of strawberry fruit ripening. Plant Physiology, 157(1), 188-199. doi: 10.1104/pp.111.177 311

Keller, M. (2015). The science of grapevines: anatomy and physiology (2nd ed.). Amsterdam: Elsevier Academic Press.
Kishino, A. Y., Caramori, P. H., Roberto, S. R., \& Ricce, W. S. (2019a). Fatores climáticos e o desenvolvimento da videira. In A. Y. Kishino, S. L. C. Carvalho, \& S. R. Roberto, Viticultura tropical: o sistema de produção de uva de mesa do Paraná (pp. 118-123). Londrina: IAPAR.

Kishino, A. Y., Marur, C. J., \& Roberto, S. R. (2019b). Características da planta. Videira ideal. In A. Y. Kishino, S. L. C. Carvalho, \& S. R. Roberto (Eds.), Viticultura tropical: o sistema de produção de uva de mesa do Paraná (pp. 187-192; 208-209). Londrina: IAPAR.

Koyama, K., Sadamatsu, K., \& Yamamoto, N. G. (2010). Abscisic acid stimulated ripening and gene expression in berry skins of the Cabernet Sauvignon grape. Functional and Integrative Genomics, 10(3), 367-381. doi: 10.1007/s10142-009-0145-8

Koyama, R., Assis, A. M., Yamamoto, L. Y., Borges, W. F., Borges, R. S., Prudêncio, S. H., \& Roberto, S. R. (2014). Exogenous abscisic acid increases the anthocyanin concentration of berry and juice from 'Isabel' grapes (Vitis labrusca L.). HortScience, 49(4), 460-464. doi: 10.21 273/HORTSCI.49.4.460

Koyama, R., Colombo, R. C., Borges, W. F. S., Silvestre, J. P., Hussain, I., Shahab, M.,... Roberto, S. R. (2019). Abscisic acid application affects color and acceptance of the new hybrid 'BRS Melodia' seedless grape grown in a subtropical region. HortScience, 54(6), 1055-1060. doi: 10. 21273/HORTSCI13872-19

Lancaster, J. E., Lister, C. E., Reay, P. F. Y., \& Triggs, C. M. (1997). Influence of pigment composition on skin color in a wide range of fruits and vegetables. Journal of American Society of Horticultural Science, 122(4), 594-598. doi: 10.21273/ JASHS.122.4.594 
Leão, P. C. de S., Lima, M. A. C., Costa, J. P. D., \& Trindade, D. C. G. (2015). Abscisic acid and ethephon for improving red color and quality of Crimson seedless grapes grown in a tropical region. American Journal of Enology and Viticulture, 66(1), 37-45. doi: 10.5344/ajev.2014.14041

Liang, Z., Yang, C., Yang, J., Wu, B., Wang, L., Cheng, J., \& Li, S. (2009). Inheritance of anthocyanins in berries of Vitis vinifera grapes. Euphytica, 167(1), 113-125. doi: 10.1007/s10142-009-0145-8

Lima, V. L. A. G. de, Melo, E. de A., \& Guerra, N. B. (2007). Correlação entre o teor de antocianinas e caracterização cromática de polpas de diferentes genótipos de aceroleira. Brazilian Journal of Food Technology, 10(1), 51-55.

Lucas, M., Jeremias, P. F. P. T., Andreaus, J., Barcellos, O., Química, D., Blumenau, U. R.,... Peralta-Zamora, P. (2008). Reutilização de efluente de tingimentos de fibras acrílicas pós-tratamento foto-eletroquímico. Quimica Nova, 31(6), 1362-1366. doi: 10.1590/S0100-40422008000600017

Machado, T. F., Monteiro, E. R., \& Tiecher, A. (2019). Estabilidade química, físicoquímica e antioxidante de polpa de Physalis pasteurizada e não pasteurizada sob congelamento. Brazilian Journal of Food Technology, 22, e2017149, doi: 10.1590/1981-6723.14917

Mascarenhas, R. D. J., Guerra, N. B., Aquino, J. D. S., \& Leão, P. C. D. S. (2013). Qualidade sensorial e físico-química de uvas finas de mesa cultivadas no submédio São Francisco. Revista Brasileira de Fruticultura, 35(2), 546-554. doi: 10.1590/ S0100-29452013000200025

Mattiuz, B. H., Miguel, A. C. A., Galati, V. C., \& Nachtigal, J. C. (2009). Effect of stored temperature in minimally processed seedless table grapes. Revista Brasileira de Fruticultura, 31(1), 44-52. doi: 10.15 90/ S0100-29452009000100008

Nachtigal, J. C., Camargo, U. A., \& Maia, J. D. G. (2005). Sistema de produção de uva de mesa no norte do Paraná: implantação do vinhedo. Bento Gonçalves: EMBRAPA Uva e Vinho.

Olivares, D., Contreras, C., Muñoz, V., Rivera, S., González-Agüero, M., Retamales, J., \& Defilippi, B. G. (2017). Relationship among color development, anthocyanin and pigment-related gene expression in 'Crimson Seedless' grapes treated with abscisic acid and sucrose. Plant Physiology and Biochemistry, 115, 286297. doi: 10.1016/j.plaphy.2017.04.007

Orak, H. H. (2007). Total antioxidant activities, phenolics, anthocyanins, polyphenoloxidase activities of selected red grape cultivars and their correlations. Scientia Horticulturae, 111(3), 235-241. doi: 10.1016/j.scienta.2006.10.019

Owen, S. J., Lafond, M. D., Bowen, P., Bogdanoff, C., Usher, K., \& Abrams, S. R. (2009). Profiles of abscisic acid and its catabolites in developing Merlot grape (Vitis vinifera) berries. American Journal of Enology and Viticulture, 60(3), 277-284.

Peppi, M. C., Fidelibus, M. W., \& Dokgozlian, N. K. (2006). Abscisic acid application timing and concentration affect firmness, pigmentation and color of 'Flame Seedless' grapes. HortScience, 41(6), 1449-1445. doi: 10.21273/HORTSCI.41.6.1440

Peppi, M. C., Fidelibus, M. W., \& Dokoozlian, N. K. (2007). Application timing and concentration of abscisic acid affect the quality of 'Red globe' grapes. The Journal of Horticultural Science and Biotechnology, 82(2), 304-310. doi: 10. 1080/14620316.2007.11512233 
Peppi, M. C., Fidelibus, M. W., \& Dokoozlian, N. K. (2008). Timing and concentration of abscisic acid applications affect the quality of 'Crimson Seedless' grapes. International Journal of Fruit Science, 7(4), 71-83. doi: 10.1080/15538360802003324

Piva, C. R., Lopez G. J. L., \& Morgan, W. (2006). The ideal table grapes for the Spanish market. Revista Brasileira de Fruticultura, 28(2), 258-261. doi: 10.1590/S0100-2945 2006000200023

R Core Team (2020). R: a language and environment for statistical computing. Vienna, Austria: R Foundation for Statistical Computing. Retrieved from https://www.R-project.org/

Rastija, V., Srecnik, G., \& Saric, M. (2009). Polyphenolic composition of Croatian wines with different geographical origins. Food Chemistry, 115(1), 54-60. doi: 10.1016/j.foodchem.2008.11.071

Ribéreau-Gayón, P., Glories, Y., Maujean, A., \& Dubourdieu, D. (2006). Handbook of enology: the chemistry of wine. Stabilization and treatments. John Wiley \& Sons, 2, 450. doi: 10.1002/0470010398. ch6

Ribichaud, J. L., \& Noble, A. C. (1990). Astringency and bitterness of selected phenolic in wines. Journal of the Science of Food and Agriculture, 53(3), 343-353. doi: 10.1002/jsfa.2740530307

Roberto, S. R., Assis, A. M. de, Yamamoto, L. Y., Koyama, R., Sato, A. J., \& Borges, R. S. de. (2013). Ethephon use and application timing ofabscisicacidforimproving color of 'Rubi' table grape. Pesquisa Agropecuária Brasileira, 48(7), 797-800. doi: 10.1590/ S0100-204X2013000700013

Roberto, S. R., Assis, A. M. de, Yamamoto, L. Y., Miotto, L. C. V., Sato, A. J., Koyama, R., \& Genta, W. (2012). Application timing and concentration of abscisic acid improve color of 'Benitaka' table grape. Scientia Horticulturae, 142, 44-48. doi: 10.1016/j. scienta.2012.04.028

Robinson, S. P., \& Davies, C. (2000). Molecular biology of grape berry ripening. Australian Journal of Grape and Wine Research, 6(2), 175-188. doi: 10.1111/j.1755-0238.2000. tb00177.x

Ryu, S., Han, J. H., Cho, J. G., Jeong, J. H., Lee, S. K., \& Lee, H. J. (2020). High temperature at véraison inhibits anthocyanin biosynthesis in berry skins during ripening in 'Kyoho' grapevines. Plant Physiology and Biochemistry, 157, 219-228. doi: 10. 1016/j.plaphy.2020.10.024

Shahab, M., Roberto, S. R., Ahmed, S., Colombo, R. C., Silvestre, J. P., Koyama, R., \& Souza, R. T. (2019). Anthocyanin accumulation and color development of 'Benitaka' table grape subjected to exogenous abscisic acid application at different timings of ripening. Agronomy, 9(4), 164. doi: 10. 3390/agronomy 9040164

Siewers, V., Kokkelink, L., Smedsgaard, J., \& Tudzynski, P. (2006). Identification of an abscisic acid gene cluster in the grey mold Botrytis cinerea. Applied and Environmental Microbiology, 72(7), 46194626. doi: 10.1128/AEM.02919-05

Souza, R. T., Roberto, S. R., Koyama, R., \& Shahab, M. (2020). Uso de reguladores vegetais para intensificar e distribuir a cor de uvas de mesa cultivadas em regiões subtropicais. (Circular Técnica, INFOTECA-E). Bento Gonçalves: EMBRAPA Uva e Vinho.

Tarara, J., Lee, J., Spayd, S., \& Scagel, S. (2008). Berry temperature and solar radiation alter acylation, proportion, and concentration of anthocyanin in Merlot grapes. American Journal of Enology and Viticulture, 59(3), 235-247. 
Tecchio, M. A., Domingues, F. J. Neto, Pimentel., A.,Jr. Silva, M. J. R. da, Roberto, S. R., \& Smarsi, R. C. (2017). Improvement of color and increase in anthocyanin content of 'Niágara Rosada' grapes with application of abscisic acid. African Journal of Biotechnology, 16(25), 1400-1403. doi: 10.5897/AJB 2017.16073

Villalobos-González, L., Peña-Neira, A., Ibáñez, F., \& Pastenes, C. (2016). Long-term effects of abscisic acid (ABA) on the grape berry phenylpropanoid pathway: Gene expression and metabolite content. Plant Physiology and Biochemistry, 105(1), 213223. doi: 10.1016/j.plaphy.2016.04.012

Wildman, R. E. C. (2016). Handbook of nutraceuticals and functional foods (2nd ed.). New York, London: CRC Press Tylor and Francis Group.
Yamamoto, L. Y., Koyama, R., Assis, A. M. de, Borges, W. F. S., Oliveira, I. R. de, \& Roberto, S. R. (2015). Color of berry and juice of 'Isabel' grape treated with abscisic acid in different ripening stages. Pesquisa Agropecuária Brasileira, 50(12), 1160-1167. doi: 10.1590/S0100204X2015001200005

Yang, F. W., \& Feng, X. Q. (2015). Abscisic acid biosynthesis and catabolism and their regulation roles in fruit ripening. Phyton, 84(2), 444-453. doi: 10.32604/ phyton.2015.84.444

Zanus, M. C. (2015). Panorama da vitivinicultura brasileira. Bento Gonçalves: EMBRAPA. Recuperado de http://www.alice.cnptia. embrapa.br/alice/handle/doc/1033264 
